\title{
Improving the Semiconductor Package Tin-flake Problem Using TRIZ
}

\author{
TRIZ를 활용한 반도체 패키지 주석 조각의 문제 개선 \\ Dong Seok $\mathrm{Oh}^{1}$, Yong Won Song ${ }^{2}$ \\ 오동석 ${ }^{1}$, 송용원 2 \\ ${ }^{1}$ Engineer, SK Hynix Semiconductor Co., Ltd., Korea, dongseok.oh@sk.com \\ ${ }^{2}$ Professor, Dept. Nano \& Semiconductor Engineering, Korea Polytechnic University, Korea, \\ ywsong@kpu.ac.kr
}

Corresponding author: Dong Seok Oh

\begin{abstract}
The semiconductor manufacturing industry goes through variety of failure reduction activities to meet the customer needs, but there are a lot of problems that follow with a faulty product during the manufacturing process. One of the most frequent activities in the field is a preventive maintenance (PM) activity to inspect defects and prevent them. In addition to preventive maintenance, as there are many problems that occur due to contamination of equipment during actual equipment operation, break maintenance (BM) due to defects is also occurring. In the field, solving these problems is a key activity. This paper is focused on dealing with the tin fragmentation problem that occurs during forming in the package trim form process during the semiconductor manufacturing post process, among many problems. Although this problem is accompanied by environmental problems as well as equipment contamination, it has not been fundamentally solved, and a simple measure of cleaning has resulted in a lot of time loss. This problem was addressed by removing part of the molded part and allowing another part to perform its function. In this paper, in order to solve the issue, the problem was proceeded step by step according to the TRIZ (Russian pronunciation of Theory of Inventive Problem Solving) algorithm ARIZ (ARIZ: an abbreviation of the Russian pronunciation of Algorism for Inventive Problem Solving). This is a case of improving productivity by reducing the time for preventive maintenance and troubleshooting by solving the tin engraving problem.
\end{abstract}

Keywords: TRIZ, ARIZ, Pakage Form Process, Tin-flake, Maintenance Time

요약: 반도체 제조 산업은 고객 니즈에 맞추어 제품을 공급하기 위하여 다양한 불량 감소 활동을 하고 있지만, 제조과정에서 제품 불량에 따른 문제가 여전히 많이 발생하고 있다. 현장은 그중 가장 많은 활동 중의 하나가 불량을 검사하고 이를 예방 하기 위한 예방정비(PM: Preventive maintenance) 활동이다. 실제 장비가 가동되는 동안 장비의 오염으로 인해 발생하는 문제가 많아 예방정비 외에도 불량에 의한 고장 정비(BM: Break Maintenance)도 많이 발생하고 있다. 현장은 이러한 문제들을 해결해 나가는 것이 핵심적인 활동이다. 본 논문에서 소개하고자 하는 내용은 많은 문제 중에서 반도체 제조 후공정 중 패키지 트림 폼 공정에서 Forming 중에 발생하는 주석 조각 문제를 다루고자 한다. 이 문제는 장비 오염뿐만 아니라 환경적인 문제를 동반하고 있지만, 근본적으로 해결되지 못하고 지금까지 세정이라는 단순한

Received: August 03, 2021; $1^{\text {st }}$ Review Result: September 21, 2021; $2^{\text {nd }}$ Review Result: November 09, 2021 Accepted: December 31, 2021 
조치로 시간적 손실이 많이 발생하고 있다. 이 문제는 성형 부품의 일부를 제거하고 다른 부분이 그 기능을 대신 수행할 수 있도록 하여 해결하였다. 본 논문에서는 이러한 문제를 해결하기 위하여 트리즈(TRIZ: Theory of Inventive Problem Solving 의 러시아 발음에 약자) 알고리즘인 아리즈(ARIZ: Algorism for Inventive Problem Solving 의 러시아 발음에 약자)에 따라 문제를 단계적으로 진행한 결과 주석 조각 문제를 해결하여 예방정비와 고장 정비 시간을 단축하여 생산성을 향상시킨 사례이다.

핵심어: 트리즈, 아리즈, 패키지 폼 공정, 주석 조각, 정비 시간

\section{1. 서론}

반도체 산업은 현재 약 $20 \mathrm{~nm}$ 이하의 선폭으로 회로를 구현하는 기술을 바탕으로 집적도와 다 적층의 초정밀 기술로 발전하고 있다. 이렇게 개발된 제품은 공정이 많고 제조 원가가 높아서 불량이 발생하면 그만큼 높은 손실이 발생한다. 그렇기 때문에 제조 현장은 실패 비용을 줄이기 위한 다양한 품질혁신 활동을 하고 있지만, 기술 분야에 직면한 상황에 적합한 방법을 모색하는 것은 매우 어려운 일이다. 그래서 제조업 기술 분야에서는 문제 유형과 관계없이 자신이 잘 알고 있거나 익숙한 문제해결 기법으로 프로젝트를 수행하려고 하기 때문에 많은 시행착오를 겪고 있다. 따라서 실무자들이 프로젝트를 수행하기 전에 문제 유형을 명확하게 파악함으로써 이에 적합한 문제해결 기법을 선택하는 것이 매우 중요하다. [1]

본 논문에서는 고질적인 문제이기 때문에 현상 파악을 통하여 문제를 정의하고 트리즈의 각종 기법을 통하여 문제를 분석하였다. 우선 시스템적 사고를 통하여 문제의 진위성 검증을 하여 문제 해결의 필요성을 명확화한다. 이렇게 명확화된 문제는 해결 가능한 자원에 대한 기능과 특성을 분석하고 각 기능에 대한 상호 작용을 분석하여 시스템 초기의 정상적인 기능을 찾는다. 기본적인 시스템에 대한 분석이 끝나면 문제의 근본 원인을 찾고 이 근본 원인을 바탕으로 기능 상호작용 분석을 하는데 이때 실제 시스템에 유해한 영향을 미치는 기능을 찾게 된다. 우리가 해결하고자 하는 문제 모델은 이 과정을 통해 찾을 수 있으며 모순 상황도 이때 찾을 수 있기 때문에 이후에 진행은 아리즈라는 문제 알고리즘으로 해결하는 프로젝트를 진행하였다.

\section{1 반도체 공정 소개}

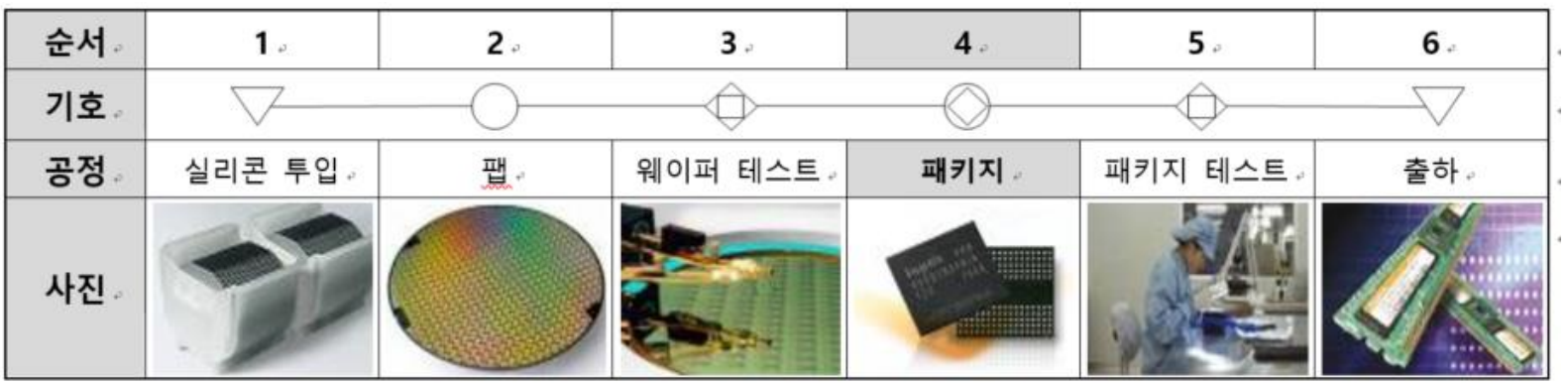




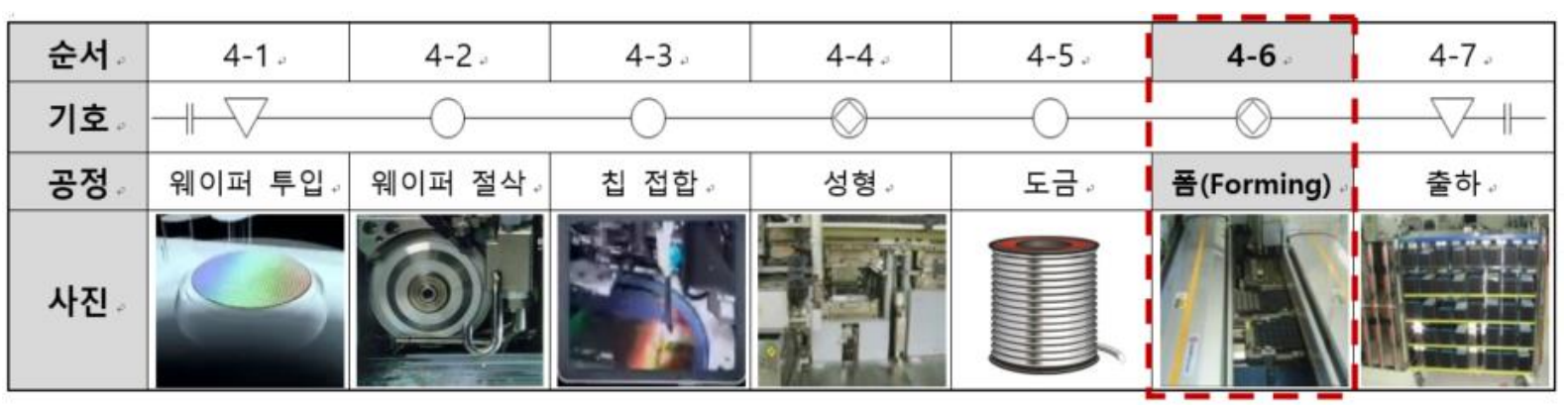

[그림 1] 반도체 공정 순서

[Fig. 1] Semiconductor Process Sequence

[표 1] 반도체 공정 소개

[Table 1] Introduction to Semiconductor Process

\begin{tabular}{|c|c|l|}
\hline 순서 & 공정 & \multicolumn{1}{|c|}{ 설명 } \\
\hline 1. & 실리콘 투입 & 낱장으로 절삭된 실리콘 웨이퍼 입고 \\
\hline 2. & 팹 & 웨이퍼 위에 반도체 회로 패턴을 형성시키는 과정 \\
\hline 3. & 웨이퍼 테스트 & 웨이퍼 상태에서 전기적 구동을 검사 \\
\hline 4. & 패키지 & 웨이퍼를 낱개의 칩으로 기능화 시키는 공정 \\
\hline 5. & 패키지 테스트 & 각 칩의 최종 전기적 구동을 검사 \\
\hline 6. & 출하 & 낱개의 제품 혹은 모듈 상태로 출하 \\
\hline \hline $4-1$ & 웨이퍼 투입 & 반제품 웨이퍼 투입 \\
\hline $4-2$ & 웨이퍼 절삭 & 낱개 칩으로 절삭 \\
\hline $4-3$ & 칩 접합 & 절단된 칩을 리드 프레임에 접착하고 칩과 리드프레임을 금선으로 연결 \\
\hline $4-4$ & 성형 & 칩을 합성 수지로 밀봉 \\
\hline $4-5$ & 도금 & 리드프레임에 주석을 도금하는 공정 \\
\hline $4-6$ & 폼(Forming) & 단품의 형상을 만들어서 분리 후 검사 \\
\hline $4-7$ & 출하 & 낱개의 제품을 출하 \\
\hline
\end{tabular}

\subsection{Forming 공정}

Forming 공정은 반도체 제품 중에 리드프레임(Lead frame: 반도체 칩을 모듈 기판에 전기적으로 연결을 하기 위한 원자재)을 이용하여 제조하는 공정 중에서 마지막 공정으로써 반제품을 기판에 부착할 수 있도록 높은 압력을 이용하여 Forming and Cutting을 하는 공정이다.

Forming Press는 모터의 회전운동을 직선운동으로 바꾸는 캠프레스(Cam Press)의 동작으로써 $\mathrm{SPM}$ (Stroke Per Minute) 90 120으로 움직인다. Lead Forming 동작 원리는 Form $\mathrm{Pad}$ 의 Stopper가 Form die의 Stopper와 닫으면서 압력이 가해지면 Cam Guide가 위로 이동한다. 이 동작으로 인하여 Cam Guide의 곡선 면이 Form Punch의 Roller와 접촉하면서 유선 운동을 하게 된다. 이런 동작이 Forming시 마찰에 의해 Lead가 손상되는 것을 최소화한다. 이 동작에서 Form pad는 Lead의 반동을 잡아주기 위해서 Clamp 한다. 


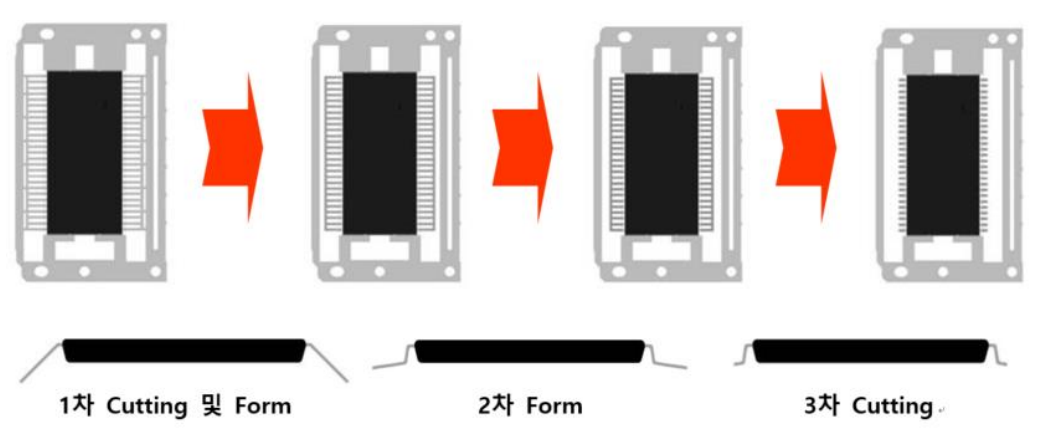

[그림 2] Forming 순서

[Fig. 2] Forming Sequence

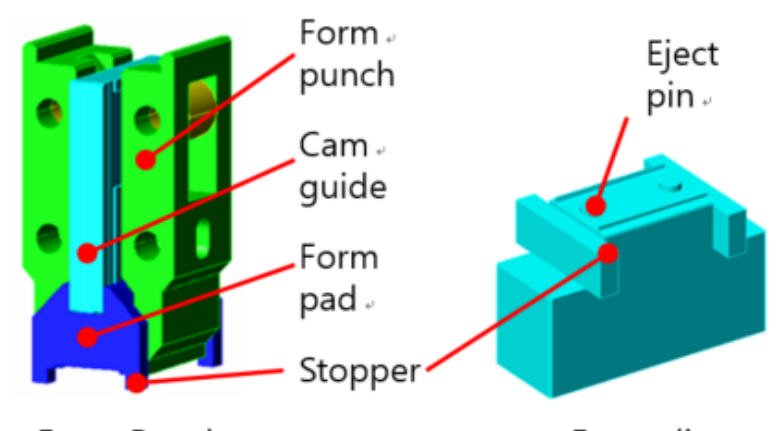

Form Punch

Form die

[그림 3] Lead Forming 파트

[Fig. 3] Lead Forming Part

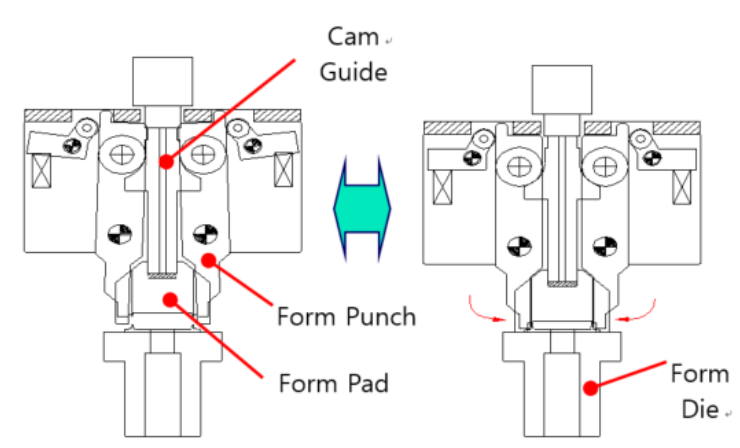

[그림 4] Lead Forming 원리

[Fig. 4] Lead Forming Principle

\subsection{TRIZ}

창의적 문제 해결 이론으로 알려진 트리즈(Theory of Inventive Problem Solving, TRIZ)는 러시아의 겐리히 알츠슐러(Genrich Altshuller)라는 발명가가 러시아 특허청에 등록된 약 150 만 건의 특허를 분석하여 수준에 따라 5단계로 나누고, 높은 3-5 수준의 문제를 어떻게 해결하였는지 분석하여 문제 해결의 공통 원리를 추출하여 만든 발명 문제해결 
이론이다. [2] 이 트리즈라는 이론의 프로세스인 아리즈(ARIZ)는 TRIZ의 문제해결 알고리즘으로서, 1956년도에 ARIZ 56이 처음 만들어졌다. ARIZ는 트리즈의 총체적인 결정판이라 할 수 있으며, 창의적 문제해결 알고리즘(Algorism for Inventive Problem Solving)이라는 러시아어 글자의 머리 글자의 영문표기를 따온 것이며, $\mathrm{ARIZ} 85 \mathrm{C}$ 는 알츠슐러가 완성한 마지막 프로세스이다. [3]

\section{2. 프로젝트 초기 상황}

\subsection{Forming 공정 고장 현황}

프로젝트 추진의 정량적 근거를 위해 문제 초기 상황인 Forming 공정 고장 정비 현황을 조사해본 결과 그림 5 와 같이 오염에 의한 고장이 $53 \%$ 로 가장 높아 중점 관리 항목으로 선정하였다.

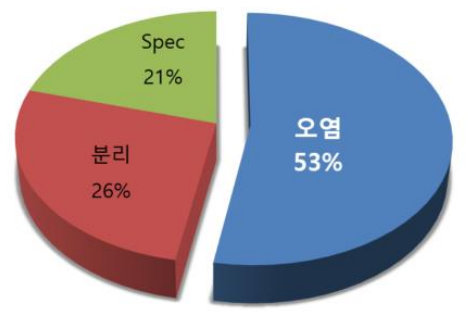

[그림 5] Forming 공정 고장 정비 현황

[Fig. 5] Forming Process BM Status

오염에 의한 고장 정비 시간을 한 달간 관리 그래프로 분석해 본 결과 그림 6과 같이 총 3 대의 장비에서 고장 정비 시간이 평균 5.69시간으로 약 6시간이 소요되고 있다는 것을 확인할 수 있었다. 한대 기준으로 보면 평균 약 2시간이 소요되고 있었으며 이 프로젝트의 관리 목표는 한대 평균 1 시간으로 설정하여 총 3 시간으로 관리되고 있었다.

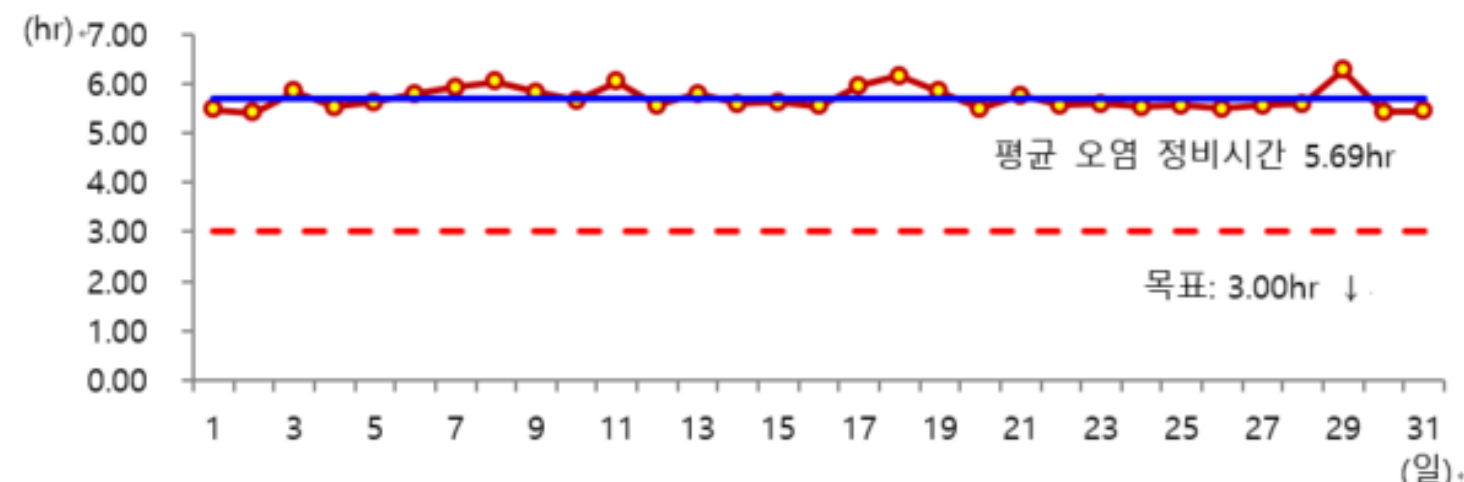

[그림 6] Forming 공정 오염 정비 시간 관리 그래프

[Fig. 6] Forming Process Contamination Maintenance Time Management Graph 


\subsection{Forming 공정 오염 현상}

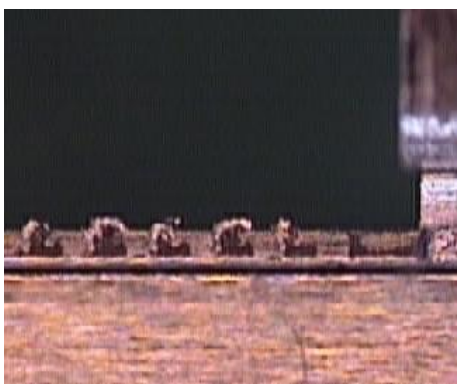

(a) Form Pad에 응착된 주석

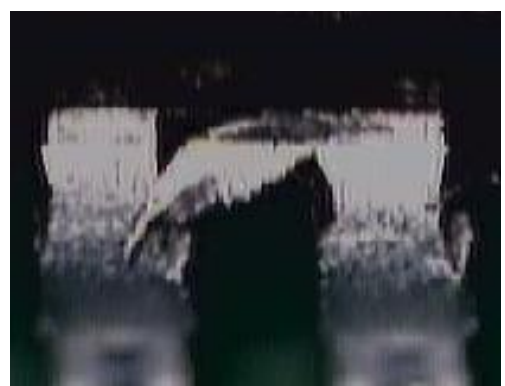

제품의 어깨 부분

(b) 고착된 주석이 떨어져 제품의 어깨로 옮겨 붙은 모습

[그림 7] Forming 파트 \& 제품 어깨 부분의 주석 조각

[Fig. 7] Forming part \& Product Shoulder Area in Tin-flake

제품의 형상을 만들어주는 Forming 공정은 형상을 만들어주는 작업에서 부품과 제품의 리드(Lead: 제품의 다리 역할을 하는 Lead frame의 일부)에서 발생하는 부하에 의해 리드에 도금된 주석 조각(Tin-flake)이 그림 7과 같이 폼 패드의 클램프 부에 누적되어 응착하여 붙어서 부품을 오염시키고 이 주석 조각이 떨어지면서 제품의 일부에 붙어서 불량을 발생시키는 현상이 나타난다.

\section{3. 프로젝트 정의}

\section{1 프로젝트 성과 지표 정의}

프로젝트 추진의 정량적 근거를 위해 성과 지표를 정의한다. 이 프로젝트의 목적은 앞서 제시한 그림 6과 같이 오염에 의한 정비가 가장 높게 차지하고 있으며 이 정비가 소요되는 일평균 시간이 $5.69 \mathrm{hr}$ 으로 높게 나타나고 있다. 이 프로젝트에서는 오염에 의한 고장 정비 시간을 단축시키는 것이 목적이기 때문에 성과 지표는 핵심 과제에 대한 도전적인 목표로 제시되는 $50 \%$ 수준인 평균 5.69 시간에서 3.0 시간 이하로 성과 지표의 목표를 설정한다.

[표 2] 성과 지표

[Table 2] Performance Indicator

\begin{tabular}{|c|c|c|}
\hline 프로젝트명 & 현수준 & 목표 \\
\hline 오염 정비 시간 단축 & 평균 $5.69 \mathrm{hr}$ & 평균 $3.0 \mathrm{hr} \downarrow$ \\
\hline
\end{tabular}

\section{2 제약조건 확인}

프로젝트를 수행하다 보면 대부분의 경우는 디자인, 재료, 조건 등의 변경이 필요한 상황들이 많지만 공정 특성상 변경이 어려운 경우가 많다. 그렇게 때문에 프로젝트를 수행하기에 앞서 어떤 제약조건들이 있는지 기술적, 행적적으로 검토하여 이 조건을 고려한 해결안을 찾도록 해야 한다. 


\subsection{1 기술적 제약조건 확인}

1) 합금 성분이 잘 못 조합되면 아래 그림 8 의 사례와 같은 현상이 발생하기 때문에 현재의 최적화된 성분 조합 비율은 변경할 수 없다.

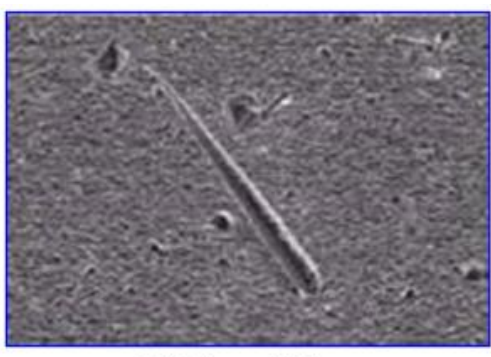

Whiskers 사례

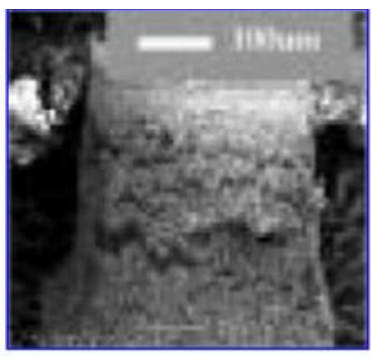

Solder crack 사례

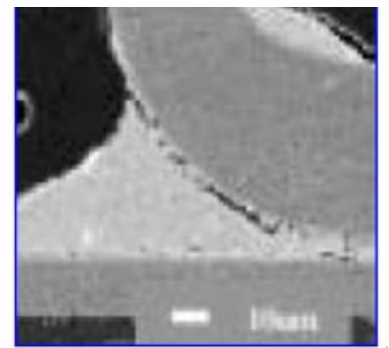

Joint open 사례

[그림 8] 기술적 제약조건 사례

[Fig. 8] Technical Constraints Examples

2) Forming 부품의 디자인은 변경할 수 있지만 burr가 발생해서는 안 된다.

\subsection{2 행정적 제약조건 확인}

1) Forming tool은 고가이므로 Forming tool 전체의 디자인은 변경할 수 없지만 부품들의 디자인은 변경 가능하다.

\section{3 프로젝트 정의}

지금까지 프로젝트 수행을 위해 문제의 초기 상황을 확인하고 성과 지표와 제약조건을 확인했다면 이제 프로젝트에서 해결해야 할 문제에 대해서 다음과 같이 명확하게 정의해야 한다. 이 단계에서 문제를 명확화하지 않으면 이후 해결안을 찾을 때 문제가 발생하는 근원적 접근보다 즉흥적 조치에 가까운 해결안이 제시되는 경우가 많다. 예를 들어서 구동부에 윤활이 부족해서 동력의 움직임이 원활하지 않은 문제가 있을 때 문제를 명확하게 정의하면 ‘구동부의 동력 전달이 부족한 현상(무엇이?)'은 ‘동력을 전달할 때(언제?)', ‘동력이 전달되는 동력 전달부에서(어디서?)', ‘구동이 원활하지 않아서(왜?)' 발생한다.라고 정의할 수 있다. 이렇게 문제가 정의되면 근원적인 접근은 근본 원인 분석을 통해서 구동이 원활하지 않은 문제는 윤활이 부족하다는 근본 문제로 분석될 수 있다. 이때 제시되는 해결안은 윤활을 새로 주입해야 한다거나 이후 장기적인 대책으로는 주기에 맞게 자동으로 윤활이 되도록 하는 대책을 제시할 수 있지만 문제를 명확하게 정의하지 못하고 현상만 보고 조치를 한다면 동력이 부족하다고 판단하여 동력부를 개선하기 위한 조치를 제시할 가능성이 크다.

1) 무엇이 문제입니까?

-> Forming 부품 및 제품에 주석 조각 오염되는 문제

2) 언제 문제입니까?

-> Forming 부품에서 제품이 생산되는 시점

3) 어디서 문제입니까? 
-> Forming 부품과 제품의 Lead가 접촉하는 위치에서

4) 왜 문제입니까?

-> 오염되는 Forming 부품

\section{4. 시스템 분석}

\section{1 다면사고 분석}

다면사고 분석이란? 우리가 다루고자 하는 시스템을 시간과 공간적인 차원에서 다양하게 사고하는 분석 기법이다. 즉 공간적으로는 하나의 시스템은 자체를 구성하는 하위(내부) 시스템과 그 시스템이 공존하거나 속하는 상위 시스템으로 나누어지며 시간적으로는 과거, 현재, 미래로 구분이 되는데 현업의 문제를 다룰 때는 공정 순서로 구분을 하면 공정 간 문제 분석에도 매우 활용도가 높다.

[표 3] 다면사고 분석

[Table 3] Multi-dimensional Analysis

\begin{tabular}{|c|c|c|c|}
\hline 영역 & 과거 (T-1) & 현재 (T) & 미래 $(\mathrm{T}+1)$ \\
\hline $\begin{array}{l}\text { 상위 } \\
\text { 시스템 }\end{array}$ & $\begin{array}{l}\text { 전기, 압축 공기 } \\
\text {, 컨베어, 매거진 }\end{array}$ & $\begin{array}{c}\text { 전기, 압축 공기, 버큠, 이송장치, } \\
\text { 가이드레일, 매거진 }\end{array}$ & $\begin{array}{c}\text { 전기, 압축 공기 } \\
\text {, 버큠, 폐기물, 트레이 }\end{array}$ \\
\hline 시스템 & 도금 고정 & Forming 공정 & 분리 공정 \\
\hline $\begin{array}{l}\text { 하위 } \\
\text { 시스템 }\end{array}$ & $\begin{array}{l}\mathrm{Sn}, \mathrm{Pb} \text {, Chemical } \\
\text {, D.I Water } \\
\text {, Lead-frame } \\
\text {, Molding pkg } \\
\text {, Sn-Pb Solder } \\
\text { Lead-frame }\end{array}$ & $\begin{array}{c}\text { Sn-Pb Solder } \\
\text {,Lead-frame } \\
\text {, Molding pkg } \\
\text {, Form punch, Form die } \\
\text {, Form pad, Cam guide } \\
\text {,Eject pin }\end{array}$ & $\begin{array}{l}\text { Sn-Pb Solder } \\
\text { Lead-frame } \\
\text {, Molding pkg } \\
\text {, Single Punch } \\
\text {, Single picker }\end{array}$ \\
\hline
\end{tabular}

\section{2 문제 진위성 검증}

문제 진위성 검증의 목적은 문제가 스스로 해결되거나, 다른 시스템에 전가할 수 있는지의 여부를 검증하는 것이다. 만약 여기서 문제가 시간 또는 공간의 변화로 스스로 해결되는 문제라면 임시적 조치만 하거나 조치를 할 필요가 없게 된다. 또는 현제 시스템에서 해결하는 것보다 타 시스템에서 해결하는 것이 효율적이라고 분석된다면 타 시스템에서 해결안을 찾는 것이 시간적, 비용적으로 효과적이다.

[표 4] 문제 진위성 검증

[Table 4] Problem Authenticity Verification

\begin{tabular}{|c|c|c|c|}
\hline 항목 시간 & 과거 (T-1) & 현재 (T) & 미래 $(\mathbf{T}+\mathbf{1})$ \\
\hline \multirow{2}{*}{ 문제해결 필요성 } & 성분 비율 변경이 어렵다 & $\begin{array}{l}\text { 도금이 밀려 떨어져서 주석 } \\
\text { 조각이 제품에 붙어있다. }\end{array}$ & 제품을 분리한다 \\
\hline & \multicolumn{3}{|c|}{$\begin{array}{l}\text { 도금 공정에서 성분 변경이 어렵고 미래, 상위 시스템으로 전가가 } \\
\text { 어렵기 때문에 현재 시스템에서 문제를 해결 해야 한다. }\end{array}$} \\
\hline \multirow{2}{*}{$\begin{array}{l}\text { 과거 시스템으로 } \\
\text { 전가 }\end{array}$} & 성분 비율 변경이 어렵다 & - & - \\
\hline & \multicolumn{3}{|c|}{$\begin{array}{c}\text { 도금 공정에서는 } 2 \text { 차 문제로 성분 비율 변경이 어렵다. } \\
\end{array}$} \\
\hline \multirow{2}{*}{$\begin{array}{l}\text { 미래 시스템으로 } \\
\text { 전가 }\end{array}$} & - & - & 분리 공정에서 제거 \\
\hline & \multicolumn{3}{|c|}{ 분리 공정에서 브러쉬로 주석 조각을 제거할 수 있지만 } \\
\hline
\end{tabular}




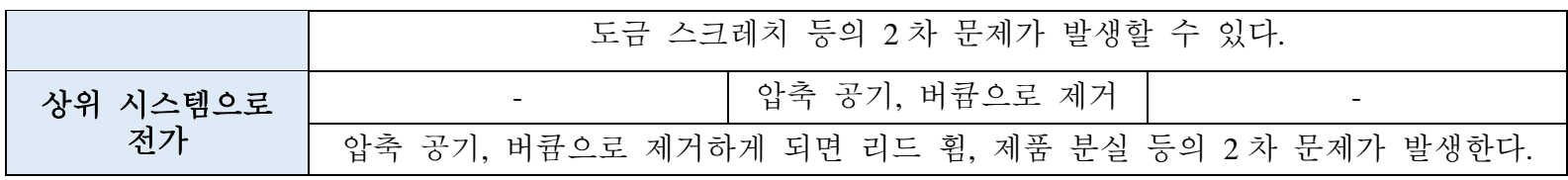

문제 해결의 필요성: 오염 정비 시간을 줄이기 위해서는 도금 공정에서 재질을 변경하여 주석 조각이 발생하는 것을 감소시키는 것이 효과적이지만 도금 공정에서는 반도체 성분 표준에 따라 성분 변경이 어렵고 미래, 상위 시스템으로 전가는 분석된 2차 문제 때문에 어렵기 때문에 현재 시스템에서 문제를 해결해야 한다.

과거 시스템으로 전가: Solder plating에서는 2차 문제로 성분 비율 변경이 어렵다.

미래 시스템으로 전가: 분리 공정에서 브러쉬로 주석 조각을 제거할 수 있지만

도금 스크레치 등의 2차 문제가 발생할 수 있다.

상위 시스템으로 전가: 압축 공기, 버큠으로 제거하게 되면 리드 휨, 제품 분실 등의 2차 문제가 발생한다.

\section{3 시스템 자원의 기능과 특성 분석}

문제를 해결하고자 하는 시스템이 정해졌다면 해당 시스템에서 존재하는 모든 자원들의 명확한 기능과 구체적인 특성을 사전에 조사하여 문제 시스템에 대한 정보를 최대한 확인한다. 보통의 경우 시스템을 개선하다 보면 수많은 장애요인과 부작용이 발생하는데 이렇게 자원들의 기능과 특성을 명확하게 습득한 후 추가적인 자원을 분석하면 개선 과정에서 시행착오를 최소화할 수 있다.

[표 5] 시스템 자원의 기능 / 특성 분석

[Table 5] Function / Characteristic Analysis of System Resources

\begin{tabular}{|c|c|c|}
\hline 시스템 영역 & 자원 & 기능 / 특성 \\
\hline \multirow{5}{*}{ 상위 시스템 } & 압축 공기 & Forming Press 에 쿠션을 만든다./ 인가 압축 공기: $45 \mathrm{kPs} \sim 80 \mathrm{Kps}$ \\
\hline & 버큠 & Lead 절단 찌꺼기를 배출 시킨다./ 전기 모터 \\
\hline & Index & $\begin{array}{l}\text { Lead frame 을 이송 한다. / 재료 : Alloy Steel (SKD 11) } \\
\text { / Index pin 이 Lead frame Hole 에 삽입되어 이송시킨다. }\end{array}$ \\
\hline & Guide rail & $\begin{array}{l}\text { Lead frame 의 이송을 가이드 한다. / 재료 : Alloy Steel (SKD 11) } \\
\text { / Lead frame 이 이송되는 위치에 } 1.0 \mathrm{~mm} \text { 의 공간이 있다. }\end{array}$ \\
\hline & Magazine & Lead frame 형태의 제품을 투입하기 위해 적재한다. \\
\hline 시스템 & Forming & Lead frame 형태의 제품을 낱개로 Forming \& Cutting 한다. \\
\hline \multirow{8}{*}{ 하위 시스템 } & $\begin{array}{l}\text { Sn-Pb plating } \\
\text { Lead-frame }\end{array}$ & $\begin{array}{l}\text { 칩을 외부의 전기적 신호와 연결한다./ 성형 반제품을 잡고 있다. } \\
\text { / 알루미늄에 주석-납 합금 도금이 되어있다. }\end{array}$ \\
\hline & 성형 반제품 & 칩과 내부 금선을 보호하는 반제품. \\
\hline & Form punch & $\begin{array}{l}\text { 제품의 리드를 굽히기 위해 형상을 가지고 힘을 가하는 부품 } \\
\text { / 재료 : Alloy Steel (초경합금: Cemented carbides) }\end{array}$ \\
\hline & Form die & $\begin{array}{l}\text { 제품의 Lead 를 굽히기 위해 형상을 가지고 있는 부품 } \\
\text { / 재료 : Alloy Steel (초경합금: Cemented carbides) }\end{array}$ \\
\hline & Form pad & $\begin{array}{l}\text { Lead 를 굽히기 위해 Form die 에 접촉하여 Lead 를 잡고 Cam } \\
\text { guide 에 힘을 전달하는 부품 / 재료 : Alloy Steel (SKD 11) }\end{array}$ \\
\hline & Cam guide & $\begin{array}{l}\text { Form punch 의 유선동작을 만들어주기 위한 Cam } \\
\text { / 재료 : Alloy Steel (SKD 11) }\end{array}$ \\
\hline & Eject pin & $\begin{array}{l}\text { Forming 이후 Form die 에서 제품을 배출하기 위한 Pin } \\
\text { / 재료 : Alloy Steel (SKD 11) }\end{array}$ \\
\hline & Lead cut punch & 제품의 Lead 를 절단하기 위해 힘을 가하는 날카로운 부품 \\
\hline
\end{tabular}




\begin{tabular}{|l|l|l|}
\hline \multirow{2}{*}{ Lead cut die } & \begin{tabular}{l} 
재료 : Alloy Steel (cemented carbides) \\
\cline { 2 - 3 }
\end{tabular} & $\begin{array}{l}\text { 제품의 Lead 를 절단하기 위해 힘을 받쳐주는 날카로운 부품 } \\
\text { Lead cut pad }\end{array}$ \\
\cline { 2 - 3 } & $\begin{array}{l}\text { 제품의 Lead 를 절단할 때 Lead 에 휨이 생기지 않도록 Lead cut } \\
\text { punch 와 함께 Lead 를 잡아주는 부품 } \\
/ \text { 재료 : Alloy Steel (SKD 11) }\end{array}$ \\
\hline
\end{tabular}

\section{4 정상적인 동작의 기능 상호작용 분석}

시스템 분석에서 기능 상호작용 분석은 자원들의 유해한 기능을 찾기 전에 초기의 정상적인 기능을 파악해야 한다. 정상적인 동작의 기능 상호작용 분석은 시스템의 정상적인 작동에서 나타나는 유익한 기능을 먼저 분석하기 위한 방법이다.

\subsubsection{Forming 기능 상호작용 매트릭스}

러시아 트리즈 전문가인 니꼴라이 스파코프스키(Nikolay Shpakovsky)의 저서에서는 시스템의 구성요소들을 정의 내린 후에 그것들 간의 모든 상호작용을 찾아야 한다. 이것을 위해 '상호작용의 매트릭스‘를 이용하는 것이 편리하다. 이것은 시스템 구성요소들의 수와 동일한 수로 된 표이다. 수직과 수평을 따라서 구성요소들의 명칭을 기입한다. 그다음 연속적으로 각 구성요소를 확인한다. 즉 만일 구성요소 'A'가 구성요소 'B'와 상호작용을 한다면 교차되는 칸에 체크 표시를 한다고 하였다. [4] 이 문제에서 기능 상호작용 매트릭스를 작성해 보면 표 6과 같다. 우선 우선 시스템 자원 분석에서 파악된 자원의 항목들을 기반으로 도구(Tool)와 대상(Object)으로 구분하여 기능 매트릭스를 만들고, 각각의 자원들 간에 상호작용이 있는 위치에 “ل” Check를 하고 작성된 기능 매트릭스를 바탕으로 기능 상호작용 매트릭스를 완성한다.

[표 6] 기능 상호작용 매트릭스

[Table 6] Function Interaction Matrix

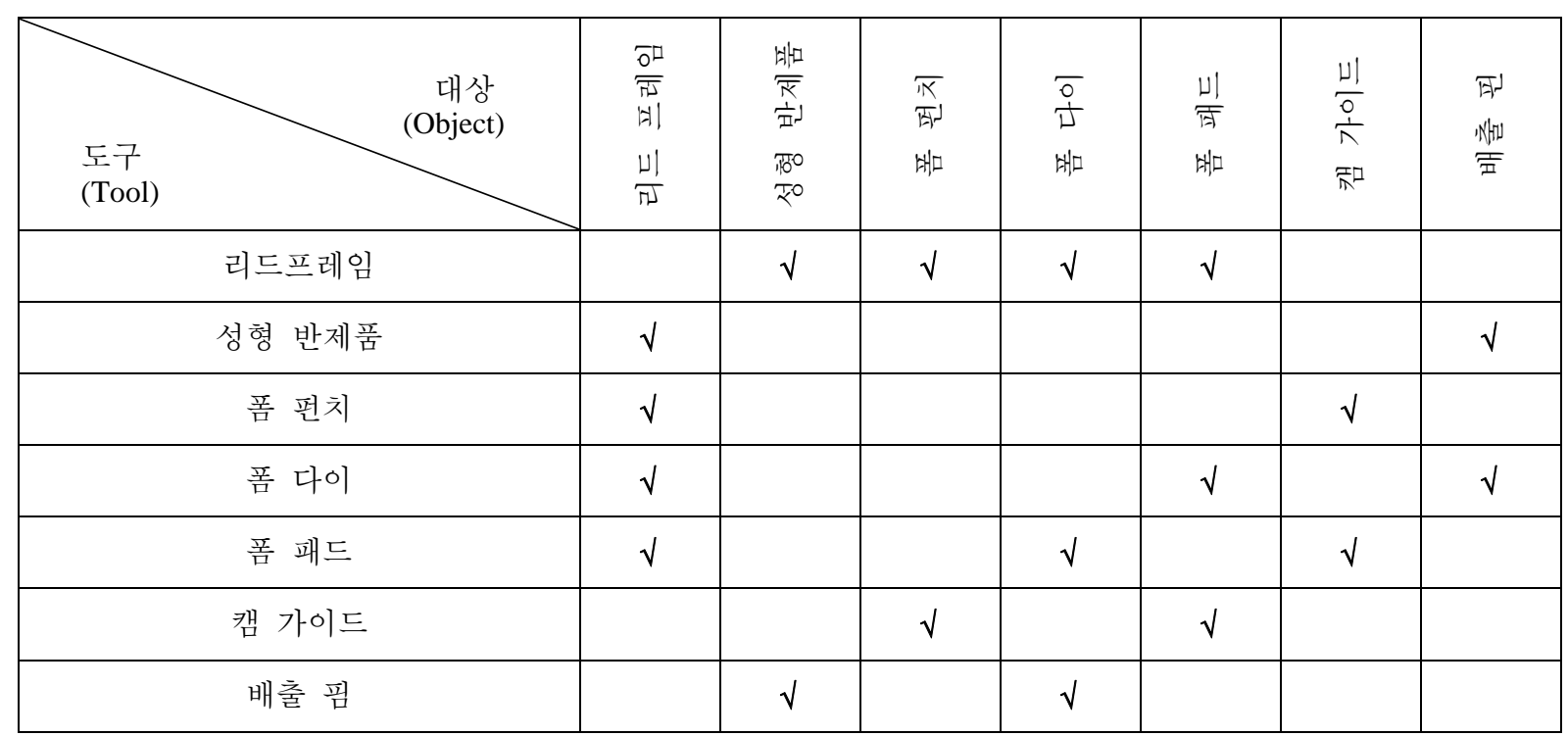




\subsection{2 정상적인 기능 상호작용 다이어그램 분석 (Forming)}

작성된 기능 상호작용 매트릭스를 바탕으로 기능 상호작용 다이어그램을 작성한다. 기능 상호작용 다이어그램은 자원들이 가지고 있는 고유의 기능들을 바탕으로 상호작용하는 상태를 다이어그램으로 표현하여 자원들의 도구(Tool)와 대상(Object)에 대한 관계를 한눈에 볼 수 있게 한다.

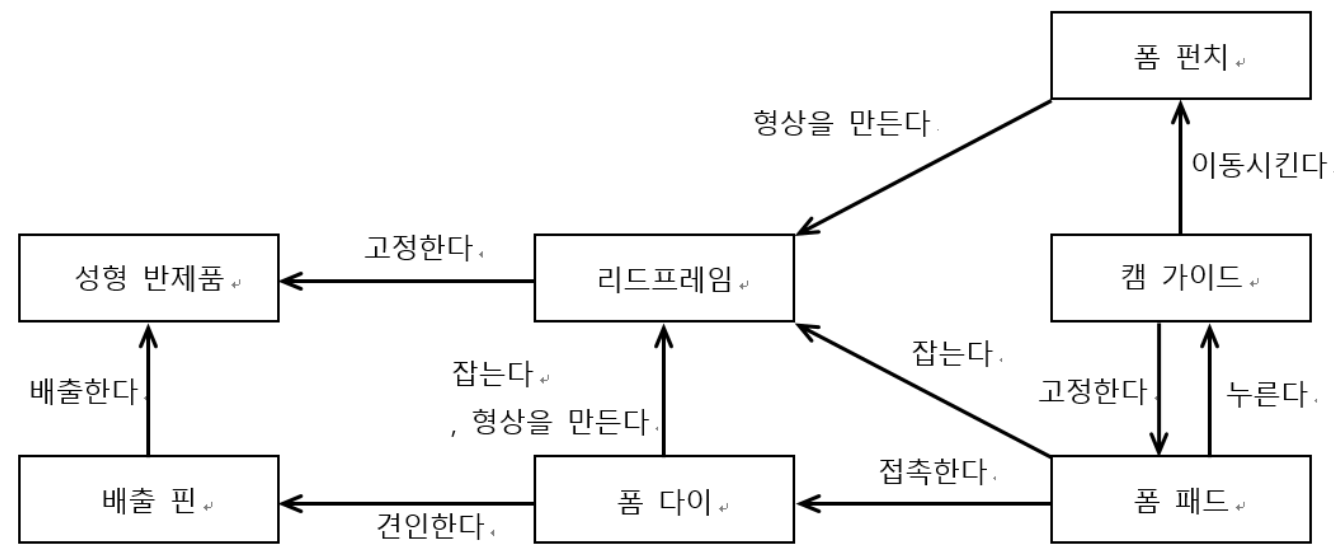

[그림 9] 정상적인 Forming 기능 상호작용 다이어그램 분석

[Fig. 9] Original Forming Function Interaction Diagrams Analysis

\section{5. 문제 원인 분석}

\section{1 근본 원인 분석}

원인 분석을 위한 도구는 많은 학자들에 의해 지속적으로 고안되고 있으며 사용자는 문제 상황에 따라 다양한 방법들을 활용하고 있다. 하지만 산업현장에서 개선을 하는 사용자가 많이 사용하고 있는 기법은 당연히 가장 기본이 되는 왜-왜 분석 기법이다. 이유는 단순하다. 가장 기본이 되는 분석 방법이면서 가장 쉽고 빠르다는 장점 때문인데 모든 원인 분석 기법에 당연히 이 방법이 근간이 되기 때문이다. 현장 과제 활동으로 가장 많이 사용되는 기법은 특성 요인도이다. 특성 요인도는 문제의 원인과 결과의 관계를 체계적으로 찾아내고, 그중 진정한 원인을 밝혀내는 기법이다. 또는 일의 결과인 특성과 그것을 유발하는 원인과의 관계를 화살표로 나타내는 그림이다. 특성 요인도는 마치 생선뼈 모양과 비슷하다고 하여 '어골도(Fishbone Diagram)'라고 부르기도 한다. 1952년 일본의 이시가와 박사가 가와사끼 제철공장에서 QC(Quality Control) 지도를 할 때 요인을 표준화하기 위해 창안한 것으로 박사의 이름을 따서 '이시가와 다이어그램(Ishikawa Diagram)‘으로 불리기도 한다. [5] 특성 요인도를 바탕으로 원인 분석을 했지만 특성들 간에 요인이 겹치거나 중복되는 상황은 ‘연관도‘라는 기법을 사용하기도 한다. 트리즈 기법 중에서도 많은 원인 분석 기법들이 존재하는데 대표적인 기법이 원인결과 사슬분석(Cause-effect chain analysis : CECA)이다. 원인 결과 사슬 분석은 여러 가지 원인이 존재하는 문제를 step by step의 형태로 체계적으로 분석하는 방법이다. 문제는 복합적인 원인으로 발생할 때가 있다. 근본원인을 발견했지만 OZ(Operation Zone, 문제가 발생하는 장소), OT(Operation Time, 문제가 발생하는 시간)에서 어떤 이유나 
규제조건으로 그곳에서 문제를 해결하지 못할때다 있다. 따라서 문제를 다양한 방법으로 해결할 수 있는 능력이 필요하다.이를 위해 원인결과 사슬분석(Cause-effect chain analysis : $\mathrm{CECA}$ )을 활용할 수 있다. $[6,7]$ 하지만 단점은 전문가가 아니면 작성이 어렵다는 것이다. 본 논문에서 다루는 기법은 산업 현장에서 가장 많이 사용되는 일반적인 왜-왜 분석이며 이 기법을 통해서 문제를 다루는 방법을 제시한다.

오염에는 다양한 원인이 있지만 여기서 다루고자 하는 문제는 주석 조각에 의한 오염이 현상에서 이미 밝혀졌기 때문에 원인 분석은 '주석 조각에 의한 오염‘을 1 차 결과로 제시하고 원인 분석을 실시하였다. 근본 원인 분석 그림 11 에서 'AND'의 의미는 원인 분석 과정에서 나타나는 양분되는 원인이 모두 해결되어야 해결되는 경우를 말한다. 반대로 양분되는 원인이 있지만 어느 한 가지의 원인만 해결되면 문제가 해결되는 경우는 ' $\mathrm{OR}$ '라는 의미의 표현을 하게 된다. 이 문제의 경우 원인이 두 가지로 나누어 진다는 의미가 되며 'AND' 상황이기 때문에 두 가지 원인을 모두 해결해야 이 과제가 해결된다는 의미를 갖게 된다. 하지만 이 논문에서는 주석 조각에 의한 오염의 두 가지 원인 중에서 '리드 어깨 영역을 폼 패드 클램프가 잡는다'라는 원인만 다루고자 한다.

‘A'로 표현한 영역은 원인과 결과로 이어지는 연결을 제거할 조치를 의미하며 이 조치가 간혹 현장에서 근원적인 해결책으로 제시되기도 한다. 여기서는 유지관리를 위한 기본적인 조치로써 근원적인 해결책은 아니다.

\section{2 근본 원인 분석 (기능상호 작용 분석)}

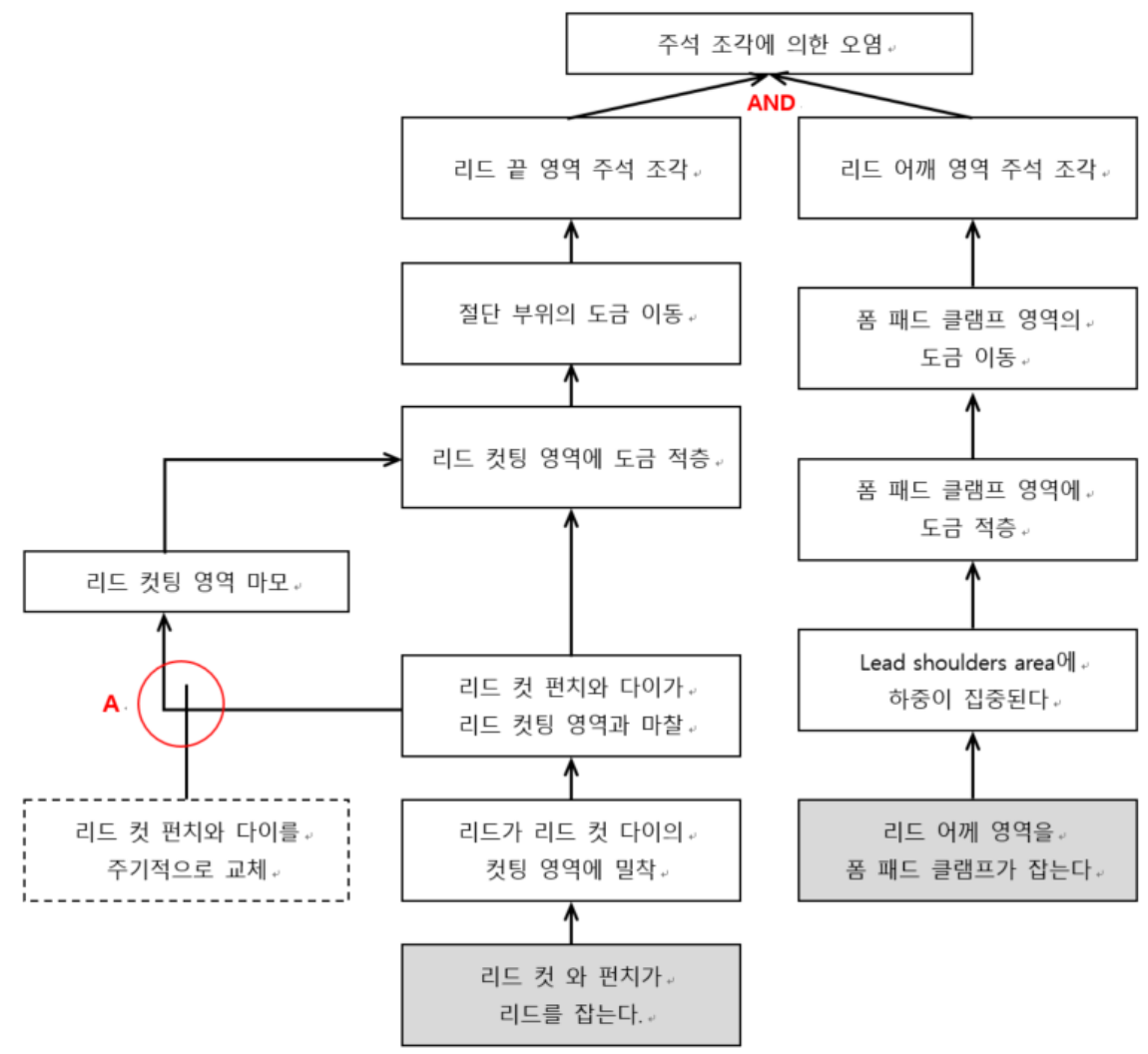

[그림 10] 근본 원인 분석

[Fig. 10] Root Cause Analysis 
트리즈에서는 기능 중심의 분석을 중요하게 생각하기 때문에 원인 결과에 대한 근본 원인분석뿐만 아니라 기능 상호작용 분석을 통하여 유해한 기능을 찾는 방법도 활용되고 있다. 앞서 작성한 정상적인 기능 상호작용 분석을 통하여 파악된 이 시스템의 명확한 기능 간의 연결 구조를 바탕으로 이제는 어떤 유해한 기능이 문제의 근원적 작용을 하는지를 찾기 위한 분석을 한다. 트리즈에서는 이 분석을 통하여 문제의 유해한 기능을 찾아내고 이 기능을 해결하기 위해 문제를 재정의하게 되는데 이 문제가 아리즈(ARIZ)에서 다루는 작은 문제가 되는 것이다.

\subsubsection{Forming 파트의 주석 조각에 의한 오염 문제에 대한 기능 상호작용 분석}

기능 상호작용 분석을 좀 더강화하기 위하여 하나의 파트라도 기능별로 구분하여 그리면 하나의 파트에서 부위별 기능분석을 할 수 있다.

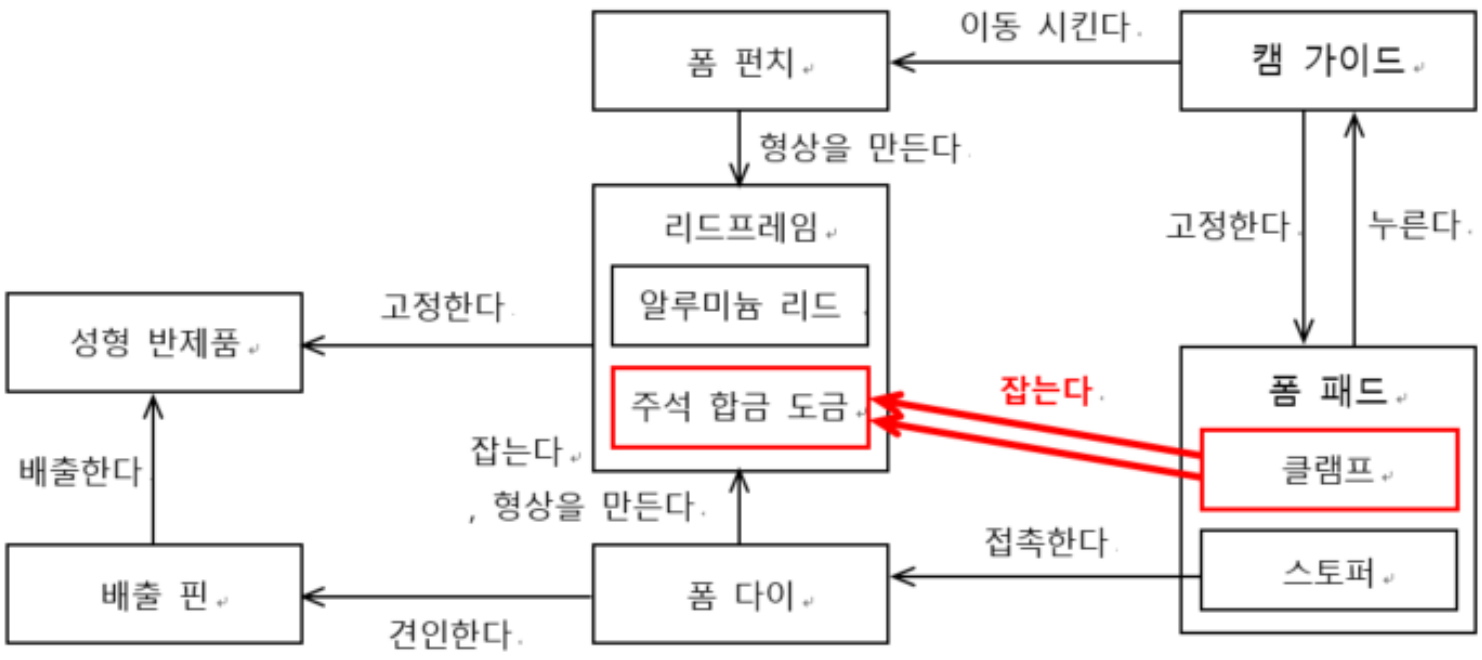

[그림 11] Forming 기능 상호작용 분석 (근본 원인 분석)

[Fig. 11] Forming Function Interaction Analysis (Root Cause Analysis)

\subsection{2 해결하고자 하는 유해한 기능 모델}

폼 패드의 클램프가 주석 합금 도금을 강하게(과도하게) 잡는다.

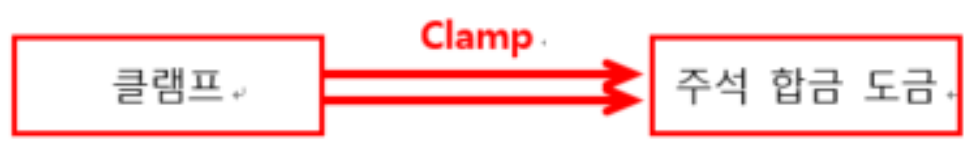

[그림 12] 해결하고자 하는 유해한 기능 모델

[Fig. 12] The Harmful Functional Model You want to Address 
폼 펀치.

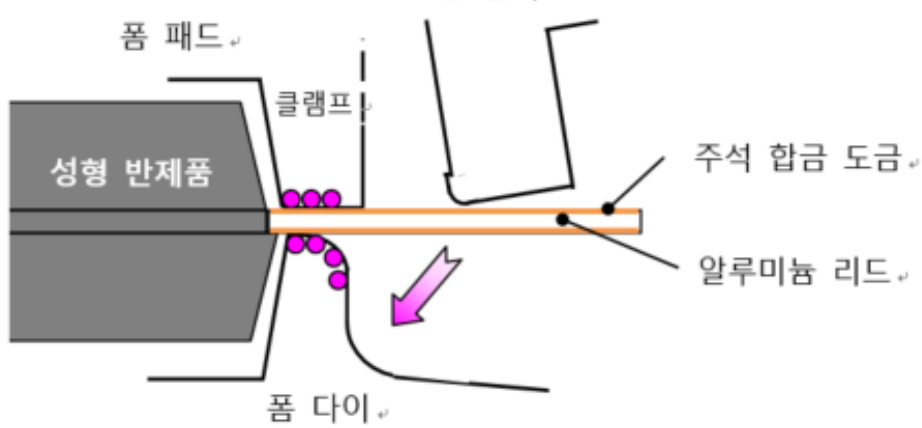

[그림 13] Forming 구조도

[Fig. 13] Forming Structure Diagram

이 경우에서 우리는 일반적 조치로 ‘폼 패드의 클램프가 주석 합금 도금을 약하게 잡는다'라는 해결안을 제시할 수 있다. 트리즈에서는 이때 발생하는 부작용의 상태나 반대되는 상태를 모순 상황이라고 한다. 이 상황도 클램프가 약하게 잡으면 알루미늄 리드를 강하게 고정하지 못해서 폼 형상을 정확하게 할 수가 없는 문제가 발생하기 때문에 모순의 상황으로 볼 수 있다. 이러한 모순 상황을 해결하는데 고안된 기법인 트리즈라는 문제해결 이론이 이 문제 상황에서 가장 적합하다고 판단하여 본 논문에서는 전통 트리즈의 알고리즘인 아리즈(ARIZ)를 따라서 문제 해결을 진행하였다.

\section{6. 문제 해결(아리즈)}

\section{1 파트 1 - 문제 분석}

\section{스텝 1.1 최소 문제}

폼 패드의 클램프가 주석 합금 도금을 강하게(과도하게) 잡는다.

[표 7] 최소 문제 정의

[Table 7] Mini Problem Definition

\begin{tabular}{|c|c|}
\hline 시스템 기능 & Forming 시스템은 제품의 알루미늄 리드의 형상을 만드는 것이다. \\
\hline 시스템 구성 & 폼 펀치, 폼 다이, 폼 패드 클램프, 알루미늄 리드, 주석 합금 도금 \\
\hline \multirow{2}{*}{$\begin{array}{c}\text { 기술적 } \\
\text { 모순 }\end{array}$} & $\begin{array}{c}\text { 기술 모순 } 1: \text { 폼 패드 클램프가 강하게 잡으면 } \\
\text { 알루미늄 리드의 형상은 정확하게 만들 수 있지만 } \\
\text { 강하게 잡는것 때문에 주석 합금 도금에 하중이 집중된다. }\end{array}$ \\
\hline & $\begin{array}{c}\mathrm{TC} 2: \text { 폼 패드 클램프가 약하게 잡으면 } \\
\text { 주석 합금 도금에 하중은 적게 받을 수 있지만 } \\
\text { 하게 잡는것 때문에 알루미늄 리드의 형상은 정확하게 만들 수 없다. }\end{array}$ \\
\hline
\end{tabular}

이 문제는 최소한의 시스템을 변경하여 ‘주석 합금 도금에 하중 없이 알루미늄 리드의 형상을 정확하게 만들어야한다. 


\section{스텝 1.2 모순 요소}

1) 대상(Product): B (알루미늄 리드), C (주석 합금 도금)

2) 도구(Tool): A (폼 패드 클램프)

Tool과 Object에 대한 관계를 한눈에 볼 수 있게 한다.

\section{스텝 1.3 기술적 모순 도식화 TC-1, TC-2}

1) TC-1: 강하게 잡은

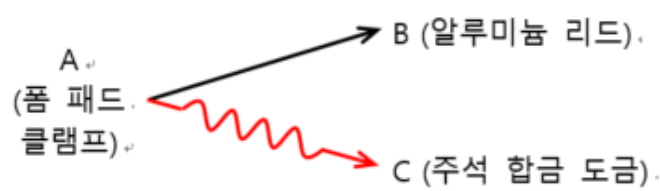

2) TC-2: 약하게 잡은

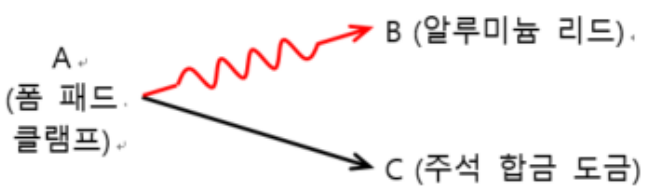

$$
\text { [그림 14] 기술적 모순 그림 }
$$

[Fig. 14] Technical Contradictions Diagram

\section{스텝 1.4 도식 모델 선정}

두 개의 도식 모델 중에서 기술 시스템이 기본적으로 수행해야 할 기능과 가장 부합하는 모델을 선정한다. 아리즈를 수행할 때 사용자가 가장 어려워하는 스템이 바로 '1.4 도식모델 선정'이다. 이 스텝이 어려운 이유는 어떤 모델을 선정하는 것이 가장 적합한 선택인지 확신이 없어서 일 것이다. 아마 지금까지는 문제 분석에 따라 순서대로 작성하면 큰 어려움이 없었겠지만 지금부터는 선택을 해야 하므로 그럴 것이다. 하지만 걱정할 필요는 없다. 어떠한 모델을 선택하더라 '파트 1'이 끝나기 전에 모델을 수정해야 한다고 판단하거나, 물리적 모순 단계로 들어가면 하나의 특성으로 “+” 이면서 “-“ 인 상황으로 모순 상황을 만들기 때문이다. 그리고, 현장에서 발생하는 새로운 문제나 고질적인 문제는 대부분 초기 시스템의 기능에는 문제가 거의 발생하지 않지만 새로운 제품 또는 조건 때문에 새로운 기능이 요구되면서 발생하는 문제가 대부분이다. 그렇기 때문에 현재 시스템에서 해결하고자 하는 핵심 문제를 중심으로 모순을 선택하는 경우도 많다.

본 논문에서도 현장에서 발생하는 고질적인 품질 문제를 다루고 있기 때문에 시스템이 가지고 있던 원래의 기본적인 기능보다는 시스템에서 수행 해야 하는 근본적인 품질 문제에 가장 적합한 모순을 선택하여 스텝을 진행해 보았다.

TC-2: 약하게 잡은

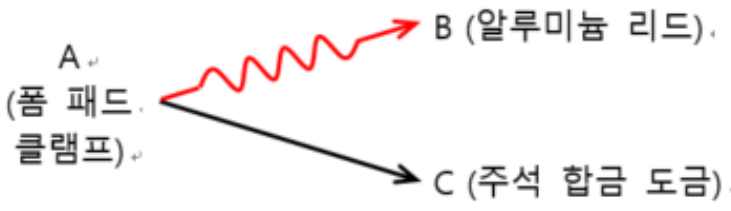

[그림 15] 선택한 기술적 모순 모델

[Fig. 15] Selected Technical Contradictions Model 


\section{스텝 1.5 모순 심화}

이 스텝에서는 선택된 기술적 모순의 특성을 극단적인 상황으로 심화시킨다. [8] 'STC 연산자(공간, 시간, 비용을 극단적인 상황으로 놓고 생각하는 발상 기법)'라는 발상법과 동일한 발상법으로 문제 상황을 최의 상황으로 악화 시켜서 문제를 다른 시작으로 바라볼 수 있게 하는 단계이다. 폼 패드 클램프의 약하게 잡는 상황은 알루미늄 리드의 형상을 정확하게 만들 수는 없는 상황이다. 이때 심화한 상황에서는 클램프가 약하게 잡는 것이 아니라 아예 클램프가 잡지 않는 것이기 때문에 폼 패드에 클램프가 없는 상황으로 심화 할 수 있다.

\section{스텝 1.6 문제 모델링}

이 스텝에서는 다음의 3 가지를 정의한다.

1) 모순 요소

대상(Product) : B (알루미늄 리드)

도구(Tool) : A (없는 폼 패드 클램프)

2) 심화된 모순 정의

약하게 잡은 폼 패드 클램프는 주석 합금 도금에 하중을 적게 줄 수 있다. 하지만 알루미늄 리드는 약하게 잡은 폼 패드 클램프 때문에 형상을 정확하게 만들 수 없다. 폼 패드에 클램프가 없는 상황에서는 주석 합금 도금에 하중은 전혀 없지만 알루미늄 리드를 잡을 수 없기 때문에 알루미늄 리드의 형상을 아주 많이 만들 수 없다.

3) $\mathrm{X}$-요소

폼 패드에 클램프가 없어서 주석 합금 도금에 하중은 없으면서 알루미늄 리드의 형상을 정확하게 만들어 줄 어떤 X- 요소가 필요하다.

클램프가 없는 폼 패드

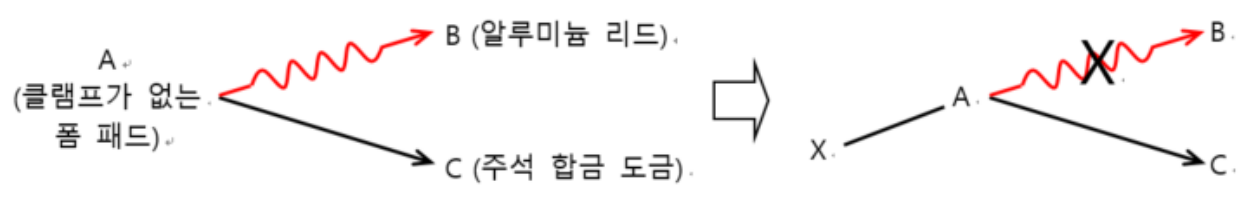

[그림 16] 심화된 모순 모델과 X-요소

[Fig. 16] Intensify Contradiction Model and X- element

이 단계까지 진행하면서 문제 모델링을 마쳤다면 스텝 1.1 에서 1.6 까지 작성된 논리를 반드시 다시 점검해 봐야 한다. 만약 여기까지 진행했는데 문제가 명확해지지 않았다거나 정리가 되지 않는다면 처음에 문제를 정의할 때 혹시 두 가지 문제를 섞어서 다루고 있지 않았는지 확인해 볼 필요가 있다. 또는 선택한 도식 모델이 본인의 논리와 맞지 않는 경우도 있으니 반드시 재 점검을 해야 한다.

\section{스텝 1.7 표준해(표준해결 모델: Substance-Field Model) 적용 검토}

이 스텝부터는 아이디어를 찾는 단계이다. 하지만 여기서 발상한 아이디어가 해결책에 가깝다고 하더라도 파트 2를 계속 진행할 것을 권장한다. 이 표준해를 이해하려면 우선 물질 장 이라는 분석법을 이해해야 한다. 물징 장은 관심의 대상인 시스템에서 두 개의 
본체를 가려낸다. 서로 다른 부품일 수도 있고 시스템과 그 제품(Product) 혹은 시스템과 환경이 될 수도 있다. 이러한 물질들은 '장(Field)'을 통해서 서로가 커뮤니케이션한다고 트리즈에서는 표현한다. 관심의 대상인 두 물질과 ,장'은 삼각형 모델로 나타내고 서로 간의 관계를 화살표를 이용하여 나타낸다. 이러한 방법으로 알츠슐러는 수십만 건의 특허의 문제와 그 해결책들을 나타내었는데 왼쪽에는 문제를 물징 장 모델로 표시하고, 그 오른쪽에는 해결책도 물징 장 모댈로 표시하였다. 알츠슐러는 이렇게 물질과 장의 모델로 분석하여 18 개의 물징 장 모델과 이와 관련된 76 가지 표준해(76 Standard Solution)를 제시하였다.

본 논문에서 클램프가 없는 폼 패드 때문에 알루미늄 리드의 형상을 정확하게 만들 수 없는 유해작용이 발생하는 상황이다. 이 문제는 물징 장 분석을 통하여 해결안을 도출해 볼 수 있다.

[표 8] 표준해 적용 아이디어

[Table 8] Standard Solution Model Idea

\begin{tabular}{|c|c|c|c|c|}
\hline 장 & 물질 & 아이디어 & 의견 & 결과 \\
\hline \multirow{2}{*}{$\mathrm{F}_{\mathrm{Me}}$} & 클램프 & $\begin{array}{c}\text { 폼 패드의 클램프 재질을 변경하여 } \\
\text { 하중을 줄인다. }\end{array}$ & $\begin{array}{c}\text { 클램프만 약한 재질로 } \\
\text { 변경이 어렵다. }\end{array}$ & NG \\
\hline & $\begin{array}{l}\text { 폼 패드 } \\
\text { 클램프 }\end{array}$ & $\begin{array}{c}\text { 폼 패드 클램프에 DLC(Diamond-Like- } \\
\text { Carbon) 코팅을 한다. }\end{array}$ & 검증결과 효과 없음 & NG \\
\hline
\end{tabular}

아이디어 1 : 표준해 1-1-1

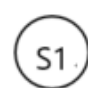

알루미늄 리드.

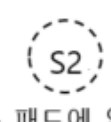

폼 패드에 없는

클램프.

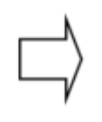

[그림 17] 표준해 아이디어 1

[Fig. 17] Standard Solution Model Idea 1

아이디어 2 : 표준해 1-1-3
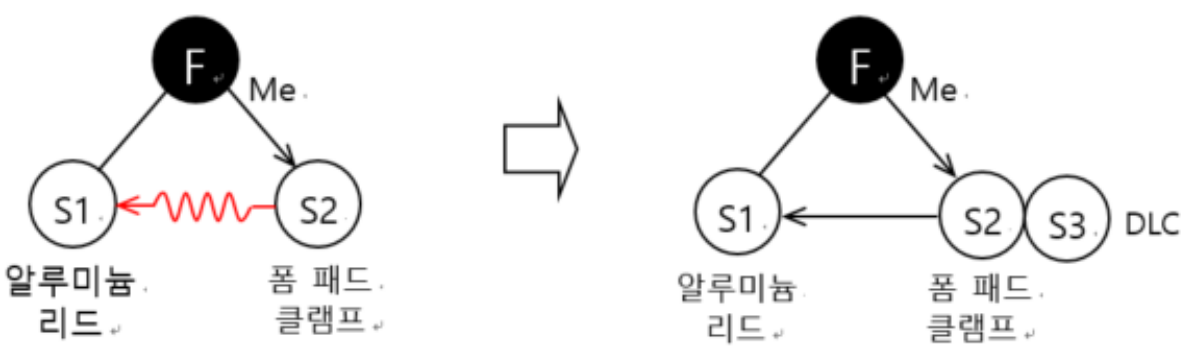

[그림 18] 표준해 아이디어 2

[Fig. 18] Standard Solution Model Idea 2 


\section{2 파트 2- 자원 분석}

\section{스텝 2.1 작용 영역(OZ: Operating Zone)}

여기서 작용 영역은 기존의 폼 패드가 차지했던 공간이다. 현재 문제에서는 클램프가 없는 경우를 고려하므로 실제 작용 영역은 폼 패드에 클램프가 없는 빈 공간이다.

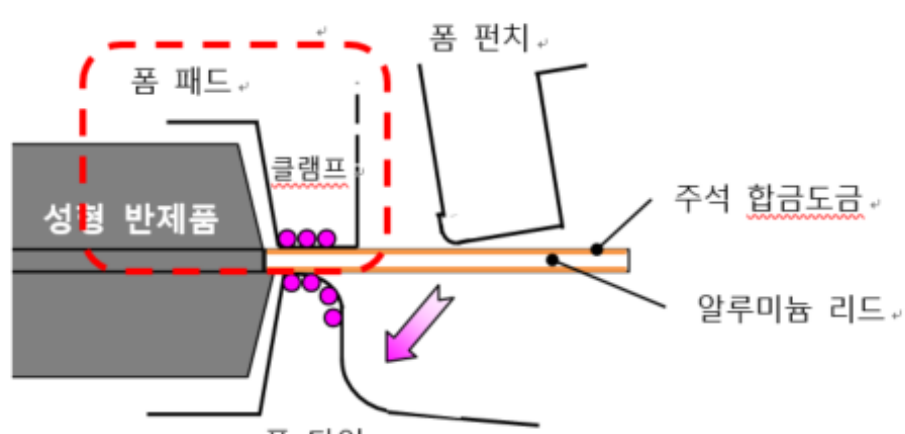

폼 다이

[그림 19] 작용 영역

[Fig. 19] Operating Zone

\section{스텝 2.2 작용 시간(OT: Operating Time)}

여기서 작용 시간은 폼 패드가 리드를 잡고 있는 시간 $\mathrm{T} 1$ 과 다음 폼 패드가 리드를 잡기 전까지의 시간 $\mathrm{T} 2$ 로 나눌 수 있다.

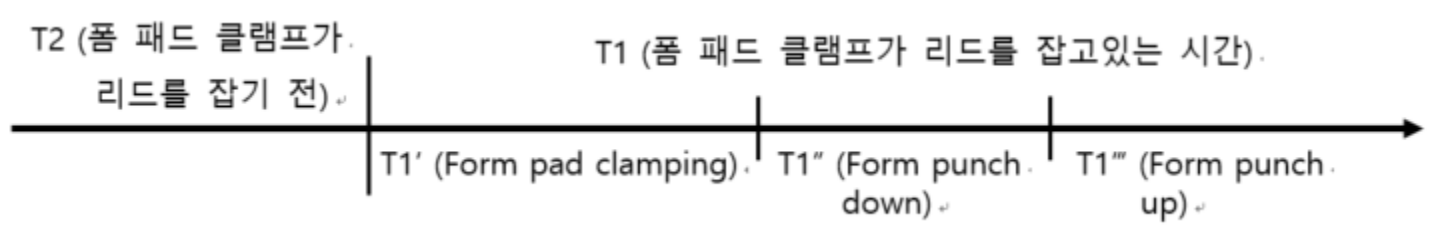

[그림 20] 작용 시간

[Fig. 20] Operating Time

\section{스텝 2.3 사용 가능한 물질-장의 탐색}

[표 9] 물질-장 자원 분석 형식

[Table 9] substance-field resources Analysis Table

\begin{tabular}{|c|c|c|c|c|}
\hline \multicolumn{5}{|c|}{ 물질-장 자원 분석, 다면사고 분석(Multi-dimensional Analysis) } \\
\hline & 카테고리 & 물질 자원 & 장 자원 & 파생 자원 \\
\hline \multirow{2}{*}{$\begin{array}{l}\text { 1. 시스템 내부에 } \\
\text { 물징 장 자원 }\end{array}$} & a) 도구 & $\begin{array}{c}\text { 폼 패드 클램프의 } \\
\text { 주변 빈 공간 }\end{array}$ & - & \multirow{4}{*}{-} \\
\hline & b) 대상 & $\begin{array}{l}\text { 알루미늄 리드 } \\
\text {, 추석 합금 도금 }\end{array}$ & 기계장 & \\
\hline \multirow{2}{*}{$\begin{array}{l}\text { 2. 주위 환경에 } \\
\text { 물징 장 자원 }\end{array}$} & $\begin{array}{l}\text { a) 주어진 환경의 } \\
\text { 물징 장 자원 }\end{array}$ & $\begin{array}{l}\text { 폼 편치, 폼 다이 } \\
\text {, 성형 반제품 }\end{array}$ & 기계장 & \\
\hline & $\begin{array}{l}\text { b) 모든 화경ㅇㅇㅢ } \\
\text { 물징 장 자원 }\end{array}$ & - & 기계장 & \\
\hline
\end{tabular}


3. 상위 시스템의 물징 장 자원

\begin{tabular}{|l|c|c|}
\hline a) 불필요한 부산물 & 주석 조각 & - \\
\hline b) 낮은 비용의 자원 & 압축공기, 버큠 & - \\
\hline
\end{tabular}

스텝 2.3에서는 폼 펀치에 클램프가 없어서 주석 합금 도금에 하중은 전혀 없는 상태를 유지하면서 알루미늄 리드를 잡을 수 없어도 형상을 정확하게 만들어 줄 X요소를 대치할 물질-자원을 분석하였다.

6.3 파트 3-이상적 해결책과 물리적 모순의 정의

스텝 3.1 이상적 해결책(IFR: Idea final result) - 1 정의

X-요소는, 시스템을 복잡하게 하지않고 동시에 추가적인 유해작용 없이

[OT: 폼 패드가 리드를 잡고 있는 시간 (T1) 또는 다음 폼 패드가 리드를 잡기 전까지의 시간 $(\mathrm{T} 2)]$ 에 [OZ: 폼 패드의 클램프가 차지하던 주변의 빈 공간]에서 [주석 합금 도금에 하중은 전혀 없는 상태를 유지하면서] [알루미늄 리드를 잡을 수 없어서 형상을 정확하게 만들 수 없는 문제]를 제거해야 한다.

\section{스텝 3.2 이상적 해결책(IFR: Idea final result) - 1 심화}

폼 패드는, 시스템을 복잡하게 하지않고 동시에 추가적인 유해작용 없이

[OT: 폼 패드가 리드를 잡고 있는 시간 (T1) 또는 다음 폼 패드가 리드를 잡기 전까지의 시간 (T2)]에 [OZ: 폼 패드의 클램프가 차지하던 주변의 빈 공간]에서 [주석 합금 도금에 하중은 전혀 없는 상태를 유지하면서] [알루미늄 리드를 잡을 수 없어서 형상을 정확하게 만들 수 없는 문제]를 제거해야 한다.

\section{스텝 3.3 매크로 수준의 물리적 모순(PC: Physical contradiction)}

폼 패드는,[폼 패드의 클램프가 차지하던 클램프 주변의 빈 공간]에서

폼 패드가 리드를 잡고 있는 시간에 알루미늄 리드의 형상을 만드는 것 때문에 잡아야 하고, 주석 합금 도금에 작용하는 하중 때문에 잡지 않아야 한다.

\section{스텝 3.4 마이크로 수준의 물리적 모순(PC: Physical contradiction)}

폼 패드는,[폼 패드의 클램프가 차지하던 클램프 주변의 빈 공간]에서

폼 패드가 리드를 잡고 있는 시간에 알루미늄 리드의 형상을 만드는 것 때문에 알루미늄 리드에 압력은 있어야 하고, 주석 합금 도금에 작용하는 하중 때문에 알루미늄 리드에 압력은 없어야 한다.

\section{스텝 3.5 이상적 해결책(IFR: Idea final result) - 2 정의}

폼 패드는, [폼 패드의 클램프가 차지하던 클램프 주변의 빈 공간]에서 [폼 패드가 리드를 잡고 있는 시간] 동안 스스로 알루미늄 리드를 고정해야 하면서 [폼 패드가 리드를 잡고 있는 시간] 이후에는 스스로 알루미늄 리드를 고정하지 않아야 한다.

\section{스텝 3.6 표준해 적용으로 물리적 모순 해결}

폼 패드의 클램프가 차지하던 빈 공간의 폼 패드는 알루미늄 리드를 잡지 않고 스스로 알루미늄 리드를 고정해야 하거나, 스스로 알루미늄 리드를 고정하지 않아야 하기 때문에 물질-장 모델에서 하나의 물질은 독립적으로 제어되는 새로운 물질-장 모델로 
변경하여 효율을 향상 시키는 표준해(Standard Solution Model) 2-1-1을 적용할 수 있다.

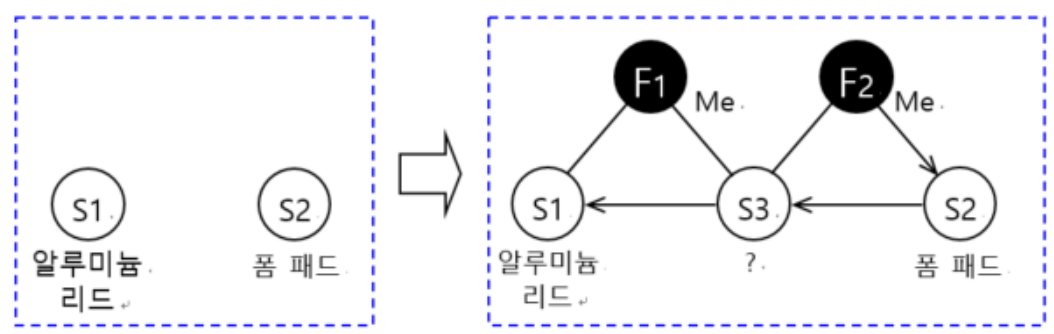

[그림 21] 스텝 3.6 표준해 아이디어

[Fig. 21] Step 3.6 Standard solution model idea

이번 스텝에서 해결안 모델을 찾는 데는 도움이 되었지만, 구체적인 컨셉 아이디어가 떠오르지 않아 다음 스텝을 추가로 진행하기로 했다.

\section{4 파트 4- 물징 장 자원의 활용}

\section{스텝 4.1 작은 사람 모델}

스텝 4.1에서 이미 작은 사람 모델로 구체적인 해결안에 대한 아이디어가 도출되었다.작은 사람 모텔에서 빨간색의 작은 사람들은 폼 펀치를 구성하는 작은 사람들 인데 이 사람들은 리드를 굽히기 위해 위에서 아래로 리드를 누르는 동작을 하고 있다. 파란색의 작은 사람들은 빨간색의 작은 사람들이 리드를 누를 때 힘이 반대로 작용하는 성형 반제품을 누르는 동작을 하게된다. 작은 사람들이 이렇게 동작을 하면 리드를 잡지 않아도 성형 반제품의 누르는 힘 때문에 리드를 잡아주는 기능이 수행된다. 스텝 4.1 이후 스텝 $4.2 \sim 4.7$ 까지 추가 아이디어를 찾아보았지만 적용 가능한 아이디어가 나오지 않아서 파트 7로 가서 해결안 검증을 실시하였다.
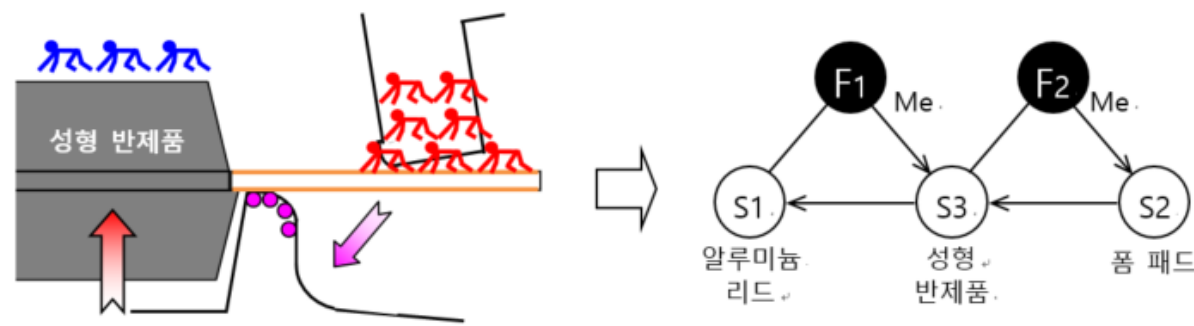

[그림 22] 작은 사람 모델 해결안

[Fig. 22] Model with small people Solution

\section{7 파트 7- 물리적 모순 해결방법 분석}

\section{스텝 7.1 개념 해결안 점검}

없어진 폼패드의 기능을 전가할 자원으로 폼 패드를 선택하였으나 스스로 알루미늄 리드를 고정할 기능을 수행할 수 없기 때문에 독립적으로 제어되는 기존에 존재하는 성형 반제품이 알루미늄 리드를 고정하도록 하였다. 


\section{스텝 7.2 개념 해결안 예비 평가}

1) 개념 해결안이 이상적 해결책-1(IFR-1)의 요구사항을 만족 하는가?

IFR-1 : 폼 패드는, 시스템을 복잡하게 하지않고 동시에 추가적인 유해작용 없이

[OT: 폼 패드가 리드를 잡고 있는 시간 (T1) 또는 다음 폼 패드가 리드를 잡기 전까지의 시간 $(\mathrm{T} 2)]$ 에 [OZ: 폼 패드의 클램프가 차지하던 주변의 빈 공간]에서 [주석 합금 도금에 하중은 전혀 없는 상태를 유지하면서] [알루미늄 리드를 잡을 수 없어서 형상을 정확하게 만들 수 없는 문제]를 제거해야 한다.

$\rightarrow$ 폼 패드는, 시스템을 복잡하게 하지않고 동시에 추가적인 유해작용 없이

성형 반제품을 고정하여 주석 합금 도금에 하중은 전혀 없는 상태를 유지하면서 알루미늄 리드를 잡을 수 없어서 형상을 정확하게 만들 수 없는 문제를 제거할 수 있다.

2) 어떤 물리적 모순이 개념 해결안에 의해 해결 되었나요?

‘폼 패드가 리드를 잡고 있는 시간에 알루미늄 리드의 형상을 만드는 것 때문에 알루미늄 리드에 압력은 있어야 하고, 주석 합금 도금에 작용하는 하중 때문에 알루미늄 리드에 압력은 없어야 한다.'의 마이크로 수준의 물리적 모순에 대한 해결안으로 제시할 수 있다.

3) 새로운 시스템이 최소한 하나 이상의 손쇱게 제어되는 요소를 가지고 있는가?, 어느 요소가 어떻게 제어되는가?

클램프가 없는 폼 패드는 주석 합금 도금에 압력을 주지 않고 알루미늄 리드를 고정 할 수 있다.

4) 여러 사이클 사용시에도 내구성에 별 문제가 없는가?

성형 반제품을 고정하는 폼 패드는 시스템에서 특별한 유지보수 없이 영구적인 사용이가능하다

\section{스텝 7.3 특허를 검색하여 특허등록 가능성 점검}

이 문제의 유사 특허를 찾을 수 없으며 추가 특허로는 진행하지 않았다.

\section{스텝 7.4 개념 해결안 실행시 발생할 수 있는 부가문제 추정}

1) 도면화

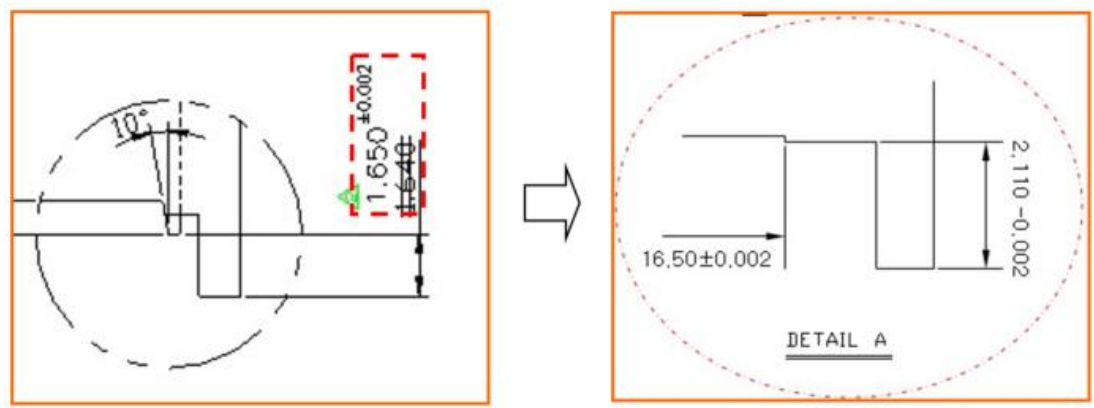

[그림 23] 해결안 도면

[Fig. 23] Solution Drawing

2) 부가적인 예상 문제에 대한 방안

- Molding PKG 두께가 변경될 수 있다.

$\rightarrow$ Molding PKG 두께 별 Form pad를 보유한다. 
이후로 진행되는 아리즈 단계는 이미 아이디어가 적용이 되어 검증이 되었기 때문에 본 논문에서는 더 이상 다루지 않았다.

\section{8 최종 해결안 적용 분석}

[그림 23]에서와 같이 개선 전에 폼 패드에는 리드를 잡아주는 클램프가 있어서 리드에 압력이 생기는 구조로 되어 있었지만 개선 후에 폼 패드에는 리드를 잡아주던 클램프는 없어져서 리드에 압력이 제거되었다. 하지만 클램프가 수행하던 리드를 고정하는 기능은 폼 패드의 윗부분이 조금 아래로 내려와서 성형 반재품을 지지하는 구조로 변경되어 그 기능을 수행하도록 하였다.
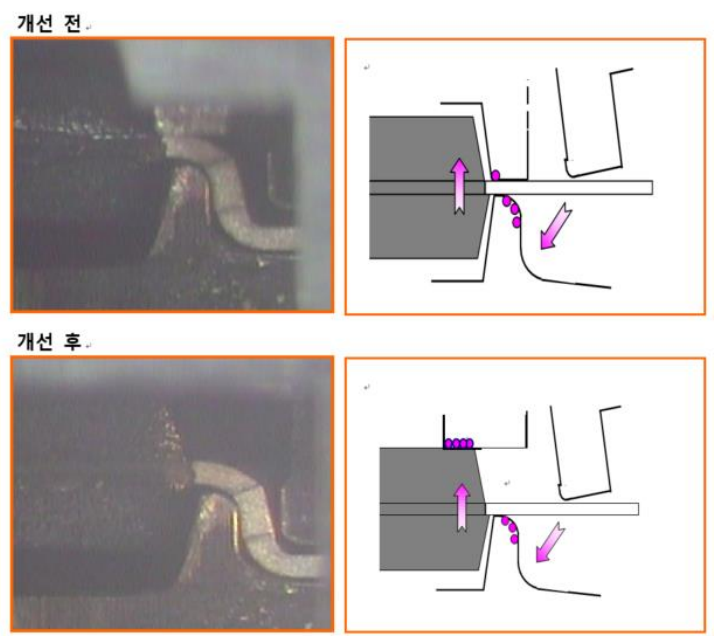

[그림 24] 해결안 적용

[Fig. 24] Apply the Solution

\section{9 결과 분석}

해결안 적용 결과 오염 정비 시간은 개선 전 $5.69 \mathrm{hr}$ 에서 $1.65 \mathrm{hr}$ 으로 $4.04 \mathrm{hr}$ 단축하면서 목표 대비 $1.35 \mathrm{hr}$ 초과 달성하였으며 관리 그래프 분석 결과 1 개월 이상 효과를 유지 하는 것으로 검증되었다.

\subsection{1 개선 효과}

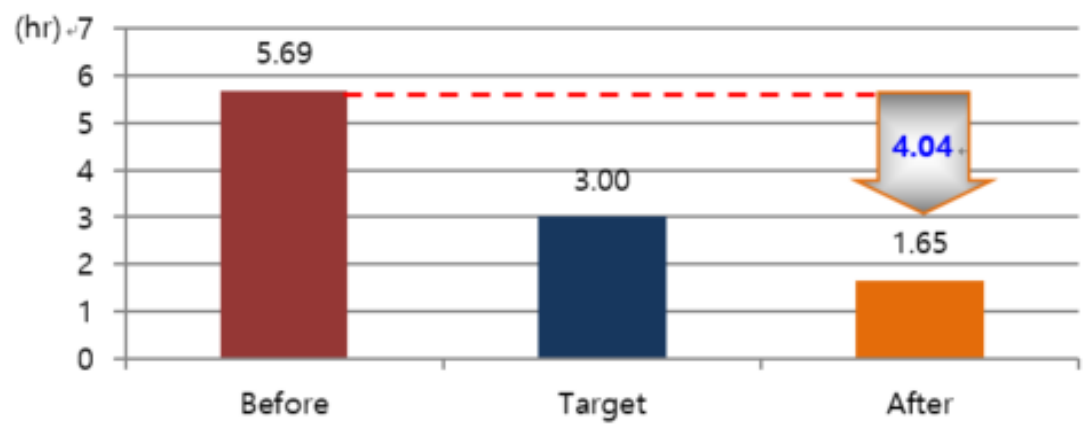

[그림 25] 개선 효과

[Fig. 25] Improvement Effect 


\subsection{2 오염 정비 시간 관리 그래프 분석}

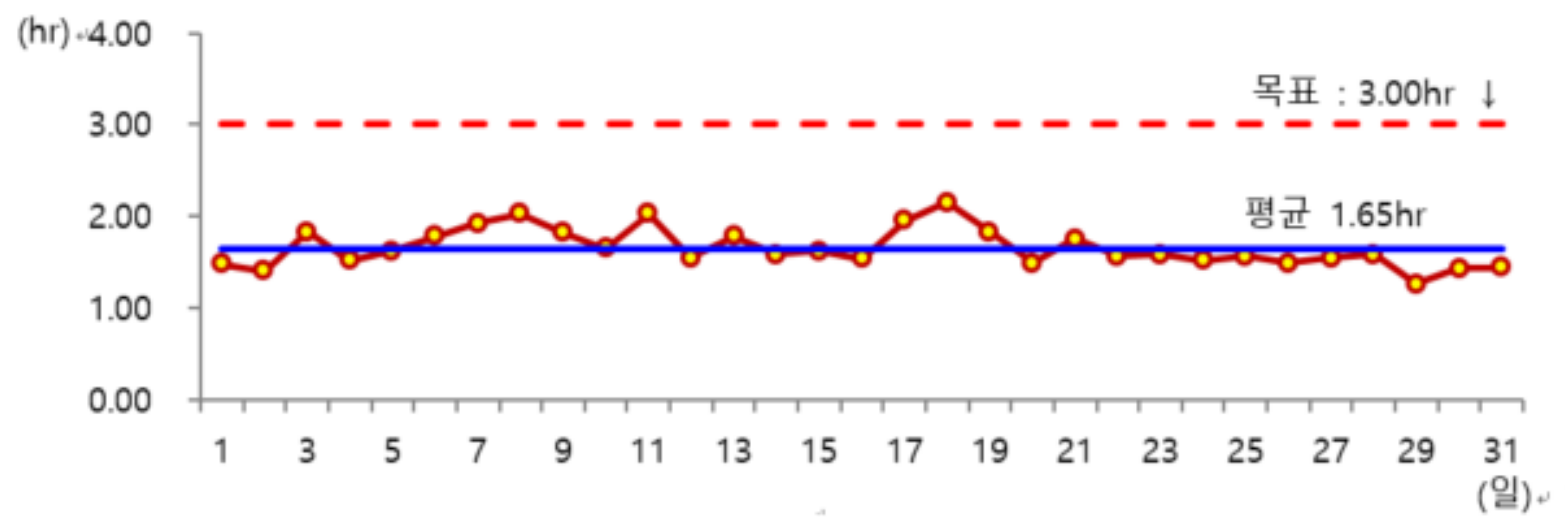

[그림 26] 개선 효과 관리그래프

[Fig. 26] Improvement Effect Management Graph

\subsection{3 재무적 성과}

부품 개선 효과금액 + 생산성 향상 효과금액 $=$ 총 비용 효과

$23,400,000$ 원/년 $+615,600,000$ 원/년 $=639,000,000$ 원/년

-. 부품 개선 효과금액: 마모로 교체된 월평균 부품수량 X 12 X 부품 단가

-. 생산성 향상 효과금액: 개선 효과시간 $\mathrm{X}$ 시간당 생산량 $\mathrm{X}$ 원가

\section{7. 결론}

본 논문은 기업 내에서 실제 TRIZ 알고리즘을 활용하여 문제 해결이 가능한지를 검증한 연구 결과이다. 특히 ARIZ는 TRIZ 알고리즘 중에서도 가장 난이도가 높고 습득하기가 어려워서 TRIZ 전문가들 사이에서도 다루기를 꺼리는 알고리즘 중에 하나이다. 하지만 그 효과성이 매우 크기 때문에 고질적인 문제를 다루는 데는 매우 뛰어난 알고리즘으로 알려져 있다. 본 논문에서 다룬 'Forming 공정의 오염 정비' 문제는 반도체 산업에서 고질적인 문제로 다루어졌기 때문에 TRIZ로 문제를 풀었지만, 지금까지고 공개하지 못했던 문제이다. 하지만 이 문제를 해결한 회사는 이제 Forming 공정을 진행하는 제품군을 생산하지 않고 있기 때문에 이제 중견, 중소기업들이 문제를 해결하는데 기술적인 이론을 제시할 수 있다. 해당 기업은 이 사례를 통하여 한 공정의 고질적인 문제를 해결하고 생산성을 향상하는데 큰 효과를 보았으며 TRIZ가 현업의 고질적인 문제를 해결하는 데 탁월한 도움이 된다는 것이 입증되어 지금도 전사에 TRIZ 교육과 과제를 독려하고 있다. 저자는 앞으로 대한민국이 기술 강국으로 거듭나는데 TRIZ 이론이 역할을 할 수 있도록 많은 사례를 만들 것이며 이 논문에서 제시하는 TRIZ의 성공 사례가 국내 많은 기업에 도움이 되었으면 한다.

\section{References}

[1] Kwangho Lee, The Between Innovation Orientation and Problem Solving Techniques and Project Performance in 
Manufacturing Technology, Chungbuk National University, Ph.D dissertation, February Page 3, (2015)

[2] H. K Shim, Y. W Song, K. J Lee, Utilization if TRIZ to Solve the Quality Problems in Semiconductor Etching Process, Asia-pacific Journal of Convergent Research interchange, (2021), Vol.7, No.2, pp.99-109, DOI: http://dx.doi.org/10.47116/apjcri.2021.02.10

[3] TRIZ nolitter, The classics described by TRIZ, Seongandang, pp.145-146, (2012)

[4] Nikolay Shpakovsky, Elena Novitskaya, TRIZ: Target Invention Practice, Duyangsa, Part2_p.137, (2012)

[5] Changnam Kim, Improvement techniques for field innovation ABC (Improvement techniques for field innovation ABC), Korean Standards Association Media, p.44, (2007)

[6] Y. W. Song, Quality and creativity_Cause-effect chain analysis, Korean Standards Association Media, (2015), Vol.469, p.83, http://www.ksamedia.co.kr/

[7] C. Dobrusskin, On the Identification of Contradictions Using Cause Effect Chain Analysis, Procedia CIRP, (2016), Vol.39, pp.221-224, DOI: https://doi.org/10.1016/j.procir.2016.01.192

[8] Hyojun Kim, Creativity of thought TRIZ, Jee Hye, pp.284-329, (2004) 